\title{
Orientalist Perspective in the Letters of Lady Mary Montagu and Kelemen Mikes
}

\author{
Neslihan Günaydın Albay ${ }^{1, *}$ \\ ${ }^{1}$ Department of English Language and Literature, Doğuş University, Istanbul, Turkey \\ *Correspondence: Department of English Language and Literature, Doğuş University, Istanbul, Turkey. Tel: \\ 90-507-332-4411. E-mail: n.albay87@gmail.com
}

Received: February 22, $2021 \quad$ Accepted: April 16, 2021 Online Published: June 17, 2021

doi:10.5430/wjss.v8n2p13 URL: https://doi.org/10.5430/wjss.v8n2p13

\begin{abstract}
An English aristocrat, poet and writer, Lady Mary Wortley Montagu (1689-1762) was a privileged and distinguished woman traveller in her time. During her sojourn in Ottoman Istanbul, she noted down significant details as regards the Constantinople and seraglio through her vivid descriptions as a liberated woman in her Embassy Letters. Another significant oriental work, Letters from Turkey by Kelemen Mikes (1690-1761), who was a Transylvanian-born Hungarian writer and political figure, is centered upon Mikes's life in exile between the years 1717 and 1758 within the boundaries of the Ottoman Empire. In Letters from Turkey, we can feel his strong sense of Hungarian identity and his steadiness in maintaining his cultural and religious customs and values in his elaboration of his own and the "other" culture, while his praising the benign and merciful ruling style of Ottoman Sultans offers a different view of orientalism in favour of the "other" culture (Ottoman Empire). Therefore, the purpose of this paper is to examine the Letters of Lady Mary Montagu and Kelemen Mikes from their political, ethnical, religious and personal perspectives and trace several relationships that has allusive discussion relativity in the discourse of Orientalism. After having explained the specific letters of both writers, I will attempt to use the scope of Edward Said's Orientalism and Enlightenment Orientalism discussed in Sirinivas Aravamudan's Enlightenment Orientalism: Resisting the Rise of the Novel, as a magnifying glass to different oriental images and conceptions contradictory with the reality in the eighteenth century. This study will mostly make use of Edward Said's account of orientalism as well as Stephen Greenblatt's theory of Self Fashioning in order to explicate the differences as to how the Orient is perceived by the authors from different cultures but from the same period. In order to highlight how the definition of Orient changes, this paper attempts to define the Orient in accordance with the works of Lady Montagu and Kelemen Mikes.
\end{abstract}

Keywords: orientalism, Lady Mary Wortley Montagu, Kelemen Mikes, letters, enlightenment

\section{Introduction}

Dealing with the histiography of narrative styles that sprang up in the Enlightenment era and their influence on European understanding of Eastern cultures and societies in mutual interaction, Sirinas Aravamudan focuses on both oriental tales and the rise of the novel in his book entitled Enlightenment Orientalism: Resisting the Rise of the Novel. In his analysis of "imaginative orientalism", he shows how the images of the East in translations and fabulist forms are subverted with the degradation of oriental tales, while the genre of domestic novel prevails until the mid 19th century. He further develops Kant and Edward Said's orientalist approach and while searching for the difference between the Saidian approach and the Englightenment orientalist mode of thinking, he indicates that "the scientific discovery and political freedom promised by Enlightenment contrast starkly with the imperial conquest and racial oppression delivered by Orientalism" (Aravamudan, 2012: 2). This idea is reinforced when he discusses that in contrast with Said's work, E.O. is a "fictional mode for dreaming with the Orient - dreaming with it by constructing and translating fictions about it, pluralizing views of it, inventing it, by reimagining" (Aravamudan, 2012: 8), rather than being a "corporate institution for dealing with the Orient" (Aravamudan, 2012: 1). He asserts that: "without examining Enlightenment Orientalism as a fictional mode, one cannot possibly understand the enormously systematic discipline by which European culture was able to manage - and even produce - both the novel and the Orient politically, sociologically, ideologically, and imaginatively during the post-Enlightenment period" 
(Aravamudan, 2012: 8).

In Stephen Greenblatt's Renaissance Self-Fashioning: From More to Shakespeare (2012), the term "self-fashioning" is defined as "the achievement of a less tangible shape: a distinctive personality, a characteristic address to the world, a consistent mode of perceiving and behaving" (Greenblatt, 2012: 2). A priviliged and distinguished woman traveller in her time, Lady Mary Wortley Montagu (1689-1762) notes down significant details as regards the Constantinople and seraglio as a liberated woman through her vivid descriptions in Turkish Embassy Letters. Offering a secular perspective on the Muslim Orient by an elite, aristocratic woman, Letters defies the restrictive social attitudes towards women that hindered their intellectual and social growth. On the other side, a series of 207 letters in an epistolary form is centered upon Mikes's life between the years 1717 and 1758. In his letters, we can feel his strong sense of Hungarian identity and his steadiness in maintaining his cultural and religious customs and values in his elaboration of his own and the "other" culture, while his praising the benign and merciful ruling style of Ottoman Sultans offers a different view of orientalism in favour of the "other" culture (Ottoman Empire).

\section{Methods}

The purpose of this paper is to examine the letters of Lady Mary Montagu and Kelemen Mikes from their political, ethnical, religious and personal perspectives and trace several relationships that has allusive discussion relativity in the discourse of Orientalism. After having explained the specific letters of both writers, I will attempt to use the scope of Edward Said's Orientalism and Enlightenment Orientalism discussed in S. Aravamudan's Enlightenment Orientalism: Resisting the Rise of the Novel, as a magnifying glass to different oriental images and conceptions contradictory with the reality in the eighteenth century. Furthermore, the common essence of both works is defining Turks as the "other". The two literary works of cultural representation reflect self-fashioning as "self-fashioning occurs at the point of encounter between an authority and alien" (Greenblatt, 1980: 9). These encounters demonstrate that European nations recreated and refashioned their identities with the creation of a non-European other. This study will mostly make use of Edward Said's account of orientalism in order to explicate the differences as to how the Orient is perceived by the authors from different cultures but from the same period, as well as Stephen Greenblatt's theory of Self Fashioning. In order to highlight how the definition of Orient changes, this paper attempts to define the Orient in accordance with the works of Lady Montagu and Kelemen Mikes.

\section{Oriental Perspective of Lady Mary Montagu}

An English well-educated aristocrat and writer who was born in 1689, Lady Mary Wortley Montagu was a privileged and distinguished woman traveller in her time because of her direct access to baths, harem (seraglio) and the Sultan's chambers within the Ottoman Empire. These advantages enabled her to contextualize her observations and provide us with a more elaborate perception of life in the 'Orient'. In her article entitled "Orientalism, Gender and Class in Lady Mary Wortley Montagu's 'Turkish Embassy Letters: to Persons of Distinction, Men of Letters \& c.", Ana Secor points out that "travelers enter a space of negotiated intercultural contact which ultimately serves to create the domestic subject, thus through the purported discovery of the spaces of the exotic, the traveler in fact explicates her own society and subject position" (Secor, 1999: 376). In her Letters, Lady Wortley Montagu presents us a critical and biographical introduction into her travels in Europe, and in Turkey in 1716 because of the appointment of her husband Ambassador. In 1716, Edward Wortley Montagu was nominated to replace Sir Robert Sutton as Ambassador Extraordinary to the Court of Turkey. He was charged to mediate between Constantinople and Vienna, which was mostly unsuccessful. These lively letters give insights into contradictory forms of freedom that Muslim women acquired by the veil. "By disrupting the foundational rhetoric of the social contract theorists that co-opts women's bodies in support of the religion / reason bi-nary, Lady Mary releases the (un)veiled woman from her role as placeholder in the East/West divide and demonstrates, in this albeit very specific context, Gayatri Spivak's model of "speaking to the other" (Heffernan, 2000: 203). The experience of observing and analyzing "the other" culture in accordance with its own value judgments and seeing herself from the eyes of others gave Lady Mary Montagu a great chance to stand out as one of the most influential and distinguished travel writers. As referred by Bernard Lewis, "from time to time a traveller manages to achieve and communicate some new insight, and thus to illuminate a patch of reality for his own and future generations" (Lewis, 1968: 300). Lady Mary Montagu's collection of letters were addressed to various friends during her travels through Europe to Turkey, the Ottoman Empire, in 1716 in order to join her husband who was a newly appointed Ambassador. According to her observations and impressions, women had more frredom at that time, especially in Turkey and Austria compared with her own country. In these letters that mostly addressed to her educated lady friends and had an eye-opening feature, Lady Mary notes down 
significant details as regards the Constantinople and seraglio as a liberated woman through her vivid descriptions. "Whether or not it is appropriate to place her in this category, one can say that Montagu was a woman of her times, an era marked by both nascent feminism and a vitriolic public discourse against women" (Secor, 1999: 380). Offering a secular perspective on the Muslim Orient by an elite, aristocratic woman, these letters defy the restrictive social attitudes towards women that hindered their intellectual and social growth.

In the fifteenth and sixteenth centuries, Ottoman Empire was both feared and respected by most western countries as an expanding power. In these centuries, a narrative emerged to reflect Muslims as followers of an Anti-Christ figure, who is an imposter and evil sensualist and this situation added more to the rest of the Orientalist discourse that creates a dichotomy between the East and the West. The East represented the sensualist, and inherently violent one, while the other represented the rational devoted Christian. Travel writing helped reinforce this theme and discourse as referred by Lady Montagu sarcastically: "I know you can have none but what is partial and mistaken from the writings of travelers" (Montagu, 1992: 162). Lady Montagu is distinguished from other Oriental writers because of her authentic description of women, including real women she encountered personally and interacted with in real life. Aesthetically she illustrates the 'exotic' aspects of 'The Ottomans' and the women figures she encounters in the Turkish baths in Sofia with an emphasis on the divine attributes of their looks and graces.

They walked and moved with the same majestic grace, which Milton describes of our general mother. There were many amongst them as exactly proportioned as ever any goddess was drawn by the pencil of Guido or Titian — and most of their skins shiningly white, only adorned by their beautiful hair divided into many tresses, hanging on their shoulders, braided either with pearl or ribbon, perfectly representing the figures of the Graces (Montagu, 1992: 105).

Lisa Lowe notes about Montagu: "explicitly challenge the received representations of Turkish society by the seventeenth-century travel writers who preceded her" - "distinctly sets herself apart from that tradition by criticizing the representations of women, marriage, sexuality and custom in the travel accounts of Robert Withers, George Sandy's, John Covel, Jean Dumont, Aaron Hill" (Lowe, 1991: 31). Referring to the fallacy of what travel writers have written about Turks superficially, without direct interaction with them or observation of their domestic life, Montagu explicates: "The Turks are too proud to converse familiarly with merchants, \&c ; who can only pick up some confused informations, which are generally false; and they can give no better account of the ways here, than a French refugee, lodging in a garret in Greek-street, could write of the court of England" (Montagu, 1992: 107).

Your whole letter is full of mistakes from one end to the other. I see you have taken your ideas of Turkey from that worthy author Dumont, who has written with equal ignorance and confidence. 'Tis a particular pleasure to me here, to read the voyages to the Levant, which are generally so far removed from truth, and so full of absurdities, I am very well diverted with them. They never fail giving you an account of the women, whom 'tis certain they never saw, and talking very wisely of the genius of the men, into whose company they are never admitted; and very often describe mosques, which they dare not peep into. The Turks are very proud, and will not converse with a stranger they are not assured is considerable in his own country. I speak of the men of distinction; for, as to the ordinary fellows, you may imagine what ideas their conversation can give of the general genius of the people (Montagu, 1992: 146).

Based on her direct observations and connections at the Ottoman seraglio, her descriptions of Pera and Constantinople in Letters, Lady Montagu is impressed by Turkish civility and morality, in contrast to the orientalist mindset that defines Turks as "barbaric, violent, ignorant, or backward". The orientalist discourse depicts the West as rational, civilized, and sophisticated; whereas Orient is cruel, uncivilized, irrational and "blind to human reality" (Said, 1978: 322). The East, does not have any existence or relevance to Europe. By creating 'self' and the 'other', Said argues that, Orient is what being Western is not. Nevertheless, Lady Montagu expresses: "I was charmed with their civility and beauty, and should have been very glad to pass more time with them" (Montagu, 1992: 106). One significant point that Montagu underlines about Turkish women is the scope of their freedom in domestic life. She comments: "upon the whole, I look upon the Turkish women as the only free people in the empire. The very Divan pays a respect to them; and the Grand Signior himself when a pasha is executed, never violates the privileges of the harem (or women's apartment), which remains unsearched and entire to the widow" (Montagu, 1992: 116). In contrast to the oriental images of women, Montagu compares: "the women here are not indeed, so closely confined as many have related; they enjoy a high degree of liberty, even in the bosom of servitude and they have methods of evasion and disguise that are very favourable to gallantry" (Montagu 1992: 149). According to Lowe, "Montagu's identification with Turkish female society invokes an emergent feminist discourse that speaks of common experiences among women of different societies" (Lowe 1991: 150).

Lady Montagu generally underscores the positive aspects of the Oriental Turks, Turkish culture and morality rather than humiliating or dictating the superiority of the West over the East. In one of the introductions to the letters Anita 
Desai writes: "Lady Mary Wortley Montagu, in an earlier age [than Fanny Park] was not called upon to establish colonial power and did not suffer from any threat to her self-confidence. She was able, in Turkey, to give full rein to the romanticism and sensuality in which she reveled" (Desai, 1999: xxxii). Another inspirational point about Turkish culture for her is how the Turkish law works. She indicates: "I am also charmed with many points of the Turkish law, to our shame be it spoken, better designed and better executed than ours; particularly, the punishment of convicted liars (triumphant criminals in our country, God knows): They are burnt in the forehead with a hot iron, being proved the authors of any notorious falsehood" (Montagu, 1992: 152). In addition, Lady Montagu draws our attention to the way how delicately Turkish people treat their slaves without any misuse or maltreatment as if they were part of their own family. She admires Turkish manners towards slaves while she mentions the attitude of Christian society towards slaves in a reproachful way:

I know you'll expect I should say something particular of the slaves; and you will imagine me half a Turk when I don't speak of it with the same horror other Christians have done before me. But I cannot forbear applauding the humanity of the Turks to these creatures; they are never ill-used, and their slavery is, in my opinion, no worse than servitude all over the world. 'Tis true they have no wages; but they give them yearly clothes to a higher value than our salaries to any ordinary servant. But you'll object, men buy women with an eye to evil. In my opinion, they are bought and sold as publicly and more infamously in all our Christian great cities (Montagu, 1992: 166).

Greenblatt defines self-fashioning:

It (self-fashioning) invariably crosses the boundaries between the creation of literary characters, the shaping of one's own identity, the experience of being molded by forces outside one's control, the attempt to fashion other selves. Such boundaries may, to be sure, be strictly observed in criticism, just as we may distinguish between literary and behavioral styles, but in doing so we pay a high price, for we begin to lose a sense of the complex interactions of meaning in a given culture." (Greenblatt, 1980: 3).

He suggests that self-fashioning is carried out when an alien and an authority interact with each other and the result of this encounter has elements from both authority and alien that will be attacked, therefore, "any achieved identity always contains within itself the signs of its own subversion or loss" (Greenblatt, 1980: 9). Self-criticism is significant to fashion the ideal self. Said' s seminal work, Orientalism and Greenblatt's concept of 'self-fashioning' can be associated in terms of not only othering but also identity building. "The construction of identity ... involves establishing opposites and 'others' whose actuality is always subject to the continuous interpretation and re-interpretation of their differences from 'us"' (Said, 2003: 332). The pioneer of the literary field of Orientalism, Edward Said expands the concept of the 'Orient' by historicising and analysing Eastern countries within the scope of two opposite concepts: inferiority and superiority. However, Said's Orientalism offers a post-colonial perspective that handles the issues of British and American colonialization period, rendering their superiority over the Orient. On the other hand, Andre Gingrich, broadens the frame of Said's Orientalism, puts forward a new theory called Frontier Orientalism in which he expands his argument on Central European countries and their cultural interaction with Muslim countries: "The Orient was almost a European invention, and had been since antiquity a place of romance, exotic beings, haunting memories and landscapes, remarkable experiences [...] The Orient is not only adjacent to Europe it is also [...] one of its deepest and most recurring images of the Other (Said, 1978: 69). Meyda Yegenoğlu comments on orientalism:

The symbolic universe of Orientalism is not without any contradictions, displacements or contestations. Orientalism establishes its unity despite the polymorphous nature of the texts that constitute it. The Orientalist universe, in its unity, is a multifarious or voluminous textuality, but these characteristics do not make it more vulnerable, or these characteristics do not in any simple way constitute a subversive challenge to its power and unity. On the contrary, they enrich the Orientalist discourse. Thus, I would prefer to be more cautious about locating the challenge of Orientalism either in the multivalent position of texts, or in attempts which offer a more "positive" and "good" picture of the Orient and Oriental women as opposed to "negative" and "bad" images (Yegenoglu, Inscriptions Vol. $6)$.

\section{Oriental Perspective of Kelemen Mikes}

On the other hand, Letters from Turkey by Kelemen Mikes addresses to an imaginary aunt and dates back to the 1700s. It is the representative of the first art prose in Hungarian written by Kelemen Mikes as a member of Prince Ferenc Rákóczi's retinue in Turkish exile. As stated by George Gömöri in his article entitled "Tradition and Innovation in the Literature of the Hungarian Diaspora", "Kelemen Mikes, a follower and secretary of Prince Ferenc 
Rakoczi II, whose fictitious letters to his aunt were published only decades after his death, is thought to be the first outstanding representative of modern Hungarian" (Gömör1, 1976: 303). Moreover, "The failure of the Hungarian Uprising and War of Liberation against the Habsburgs led by the Hungarian nobleman and prince of Transylvania, Francis II Rákóczy (1676-1735), in 1711 forms a clear rupture in Hungarian history" (Jensen, 2016: 242). The Hungarians, who were destitute and dependent on the charity of the Porte in most cases by now, had nowhere to go and were forced to remain in Turkey. These letters enabled Mikes to establish himself as one of the creators of Hungarian prose. Being the scribe of Hungarian Prince Ferenc II., Kelemen Mikes was born in 1690 in the Transylvanian village of Zagon, County Hiromszek. Following his defeat in the war of freedom against Habsurg dynasty in 1717, he accepts the invitation of the Turkish Sultan, Ahmed III and settles in Büyükdere, Rodosto (Tekirdağ) then in 1720.

Entering the Prince's service in 1707 Kelemen Mikes accompanied him into exile. Out of a bookish disposition, he widely read in Latin and French, and in his years of exile he produced great corpus of translations of religious, philosophical, and material, together with The Letters. The aunt whom Mikes addresses to in The Letters seems to be living in Pera (Beyoğlu in Istanbul), in fact she does not exist. This aunt is imaginary and these letters represent Mikes's memoir including forty-one years in his life and written irregularly during this time process. They have a lot of significance as historical document as well as having high literary quality. Aravamudan points out that "as it can be argued that the novel has already "won"-or, alternately, it might break the existing paradigm of nation based novel studies and find its way to a global comparativism that is not seduced by modernity narratives rooted in a poor evaluation of the literary-historical and cultural evidence" (Aravamudan, 2012: 7). Mikes's depiction of the lot of the exile is original in that it was not emotional. It has a sad tone but never humble or self-pitying. Even if his hope of returning to Hungary was lost, he never yielded to despair and lost his loyalty to his Prince and his love for his native land. Most probably, struggling in a sense of isolation and loneliness in exile in a foreign country, Mikes tended to write these letters in order to alleviate the dire situation that he was exposed to.

I dare no more wish you a Merry Christmas as custom requires; for you have-now adopted an alien custom. In foreign countries, especially in France, they exchange greetings only at New Year: whereas we do it on the three great festivals. Which custom is the better? That I leave to the learned. Let each country observe its own custom-that is best. I too would observe my own, were it possible, and would send some news, if there were any: but here we lead a life of such utter peace that it seems that elsewhere everyone is dead, and we alone are alive. But if we consider the matter properly, others are alive and we are just asleep. But has the exile anything else to do? (Mikes, 2000: 147)

In these letters Mikes covers various themes such as hopelessness of seeing Hungary again, his thwarted desire to get married, political activities in Turkey and abroad, and portrayals of various events and places. Mikes was a devout man and touches on religious themes with a tolerant view of Islam while he reciprocates the contempt of the Moslems for the Christians. Whatever he experienced in his exile, he never loses his devotion to the person of the Prince. On his death, Mikes did not attempt to return to Hungary. Instead, he preferred settling in an alien land in which he would spend the rest of his days without speaking its languages, any prospect of wealth, marriage or promotion, no outer friendship except for his circle of exiled Hungarians.

The Enlightenment highlighted the eighteenth century. Both Lady Montagu and Kelemen Mikes wrote their own observations and experiences in foreign lands that were conflicting with their mindset. They mirror the worldview of their own people and the personal observations of 'the other' people in their literary works. Aravamudan suggests that "travel writing is ... also expected to fulfill pre-existing stereotypes (Aravamudan, 1995: 73)". Published posthumously, Letters by Lady Montagu and Letters from Turkey by Kelemen Mikes include fictional elements along with personal feelings and thoughts narrated truthfully. Aravamudan notes:

Exoticism and the Enlightenment, G. S. Rousseau and Roy Porter - they agree that "arguably, however, there was a moment of equilibrium in the eighteenth century [when] Europe and Asia were still finely balanced" [...] "because of the power of Enlightenment pens, Europe itself was sufficiently self-critical and free from bigotry to be able to confront other cultures, admittedly not as equals, nor even necessarily on their own terms, but at least as alternative versions of living (Aravamudan, 2012: 7).

Both Lady Mary Montagu and Kelemen Mikes find an opportunity to express their observations about the Ottoman Palace and the events there in detail. Mikes's former experiences helped him to form his opinion about the Ottoman stately administration at that time. Beginning from the 18th century, there were some degrading factors that led to the collapse of the Empire by weakening it gradually. Among these were the system of "devshirme" (selection of non-Christian subjects, their conversion to Islam and promotion by merit) and choosing freeborn Muslims for high 
offices. Kelemen Mikes also shares the same observation about this "devshirme" system. He also makes a criticism of the frequent changes in the assignment of grand viziership whose holders he saw as "the god of the world with richness worthy of kings" (Mikes, 2000: 22). He observes that Turks do not separate religious and administrative laws from each other. He appreciates that Turks respect Christ and explicates:

I cannot end my account of the Turkish religion better than with a reference to their respect for Christ. It is untrue that they curse Him, as many maintain: for in this one must have regard not to the common people, but to the scribes. But if they are so unfortunate as not to believe in the divinity of Christ, they do at least revere Him as the Breath of God, as a great intercessor with the Lord. They agree that God sent Him forth, to bring a law that is full of grace. But when they call us infidels it is not because we believe in Christ, but because we do not believe that Mahumet was sent from God. We are right in so doing (Mikes, 2000: 237).

While Mikes refutes some stereotypes about Turkish people and Turkish religion out of misunderstandings, he is persistent in justifying his own cultural beliefs and practices against the "other" culture and religion. This partiality has something to do with his unfamiliarity with this foreign culture and the power struggle between Islam and Christianity. The common misconception about the image of Turks cursing Christ turns into a more lenient judgment in Mikes's letters although we come across traces of the strife that stigmatizes and denounces Islam against Christianity, based on Mikes's cultural and ethnical identity during his exile away from his homeland and people within the borders of the Ottoman Empire. This situation drove him more into isolation and led him to cling to his religion more, which creates a gap between the dogmatic values of Islam and the conservative perspective of Christianity throughout his letters. He mirrors this religious conflict with these words: "Now I must write of the Turkish religion: and say that of all false religions that of Mahumet is the most dangerous, because apart from the fact that most of all it favours the senses, on a number of points it is in agreement with Christianity" (Mikes, 2000: 230). He elaborates this situation:

Truly, the Turks like us, we have nothing to complain of, none does us harm, but it is hard for a foreigner here; for he can make no acquaintances or friends. This nation does not hate the Christian but despises him. We cannot expect anyone to invite us to his house. Certainly, I have no great wish that they should, why should I? They give one a pipe' of tobacco, a cup of coffee, then a couple of words followed by a long silence; then when they bring out the incense-burner that means that it is time to decamp (Mikes, 2000: 5).

Mikes tells the story of an Italian lord that warns his servants against killing animals in his hunting-park; otherwise, he will show them no mercy. One of his servants shoots a stag accidentally while he was aiming at a bird on the ground and decides to flee the country. When the lord realizes the servant shot the deer, he traces the servant who was kidnapped by pirates, and was in Africa at that time and manages to bring him back to his court after paying a large sum of money for his release. Although the servant wanted to defend himself, the Italien lord does not listen to him and had this wretched ald killed. After completing the story, Mikes verifies his aunt's opinion about the Italians again: "But it is impossible that I should not write you just one more bloodthirsty story, and no more. It comes to my mind since you tell me how vengeful the Italians are (Mikes, 2000: 143)" by stating, "that is the true Italian nature". As emphasized by Edward Said, "European culture gained in strength and identity by setting itself off against the Orient as a surrogate and even underground self" (Said, 1979: 3). Mikes resorts to racial stereotypes about other countries that reflect his prejudices about the "others": "The French and the English have declared war on one another. The English are very merciless, hard of heart and ungrateful. The other day I read of an Englishman who was the Archduke of the ungrateful (Mikes, 2000: 249)". In addition, Mikes cannot forbear criticizing Turks with an orientalist mentality owing to their strict governmental rules and management of state affairs: "What is the cure for such disorder? Severe punishment, for he that moves against the empire is quickly killed, and by this bit the pashas are held in check. Harshness and violence are the nature of the Turk" (Mikes, 2000: 225). As Edward Said states, "the European encounter with the Orient, and specifically with Islam, turned Islam into the very epitome of an outsider against which the whole of European civilization from the Middle Ages on was founded" (Said, 1979: 70).

Furthermore, Mikes gives us detailed examples about the Turkish way of thinking, their piorities, their manners and customs in several occasions, such as management style besides shedding light upon how they regard and position themselves in life. Exhibiting an apparent concern for the configurative feature of the government style in the Ottoman Empire in the letters, Mikes cannot help making a criticism of the state of the affairs being implemented in the Porte. He determines and suggests solutions to the fundamental problems concerning the functioning of the Porte. Ironically, he refers to the government style within the empire: "in the first place, it is impossible not to be sufficiently amazed at the lasting of this great empire for so long a time, and not to attribute its growth by military conquest to the ordinances of God rather than to the Turks' style of government, or the wisdom of those that govern" 
(Mikes, 2000: 224-225). He comments

If the Head of the Chancellery is dismissed, all the officials of the Chancellery, the scribes and clerks, remain, and the new Chancellor quickly learns from them what business is in hand and follows them. The new Treasurer likewise learns from his inferiors how the Treasury is organised. In this way the newcomers soon become old hands and the conduct of affairs and organisation do not change with the replacement of officers. The affairs of state simply proceed as before, but it seems to me that if a good Vizier were left in post for a long time, they would proceed even better. But what am I to say, Ibrahim Pasha was Vizier for a long time, and for that reason came the final attack: for whereas while they are still Viziers their power is very great, it is all but impossible for them not to abuse their power. And this the one never learns from the other-they are all from the same mould (Mikes, 2000: 146).

Mikes informs her imaginary aunt that the news of the Sultan's death was received as an exhilarating fact that emphasizes the cultural power relations at stake. Mikes's statements about this event are contradictory. On the one hand, he praises the Sultan's benign personality and merciful ruling style. On the other hand, he does not find the government style of the empire based on wisdom and experience transferred from senior rulers to newcomers logical enough. "Dear Aunt, can there be greater news to write than the death of a mighty Sultan? Today we heard that yesterday Sultan Mamut departed the world [....] He was much loved by the people, Christian and Turk alike; he himself was well-disposed towards the Christians [....] Now we are the guests of a third Sultan. God's holy Majesty feeds us plenteously from their hands" (Mikes, 2000: 246-247). As regards Turkish governmental customs, Mikes's views:

Among their other good qualities, the Turks esteem obedience most highly... For this same reason all that are in official positions are given the name of kul, that is, they are the Sultan's slaves. Even the Grand Vizier deems it a great honour to give himself this title. It could be said that the whole empire consists of slaves... This is why the Turks are so inclined to serve as slaves... (Mikes, 2000: 226).

This observation based on Turkish social and cultural structure marks the value and significance given to the concepts of loyalty and obedience not only in social circles but also in the hierarchical governmental system for the maintenance of order. Mikes attributes Turks' tendency to serving as slaves to their submissive nationalistic nature. Throughout the letters, we are encountered with various customs that are performed in Porte and Tekirdağ that shaped the Turkish experience in the early and middle 18th century. Thus, Letters from Turkey uncovers a great deal of information about both 18th-century Tekirdag and the impacts of Ottoman sovereignty on other cultures in general. Referring to the great importance of the letters in her conference text 'Bir Yabancı Gözüyle Tekirdağ: Kelemen Mikes'in Mektupları' Yıldız Aydın points out, "Probably nobody has given us as much information regarding the 18th century Tekirdağ as Mikes did (Aydın, 2015: 447)". Moreover, Mikes illustrates one example of Ottoman marriage customs as follows:

On the day of the wedding the bride is taken to the groom's house with great ceremony, with pipes and drums. The groom awaits her at the door and takes her down from the wagon, they take one another's hands, but the girl's face is covered so that she cannot be seen, but she can see the groom. When she has got down from the wagon, they exchange vows, then the day passes in hospitality, the men in one place, the women in another. In due course some female relative of the bride takes her to the groom's house and only then does he see whether she is handsome or ugly. Such a marriage is not to them Hungarian taste (Mikes, 2000: 239).

From his narrative style, it is obvious that his comparison of an Ottoman tradition to that of a Hungarian one could only be because of his reflections on his culture due to loneliness. However, his comment of "such a marriage is not to them Hungarian taste" inhabits his nationalistic and demarcative outlook and stance between his descriptive object and his own culture in his comparative work Letters from Turkey. For instance, regarding the Alkoran as the religious book of Turks, he portrays: "the book of alkoran is a book in which, among the good things there are much childishness and futility. But this book, whatever it may be, nevertheless sets forth both priestly and civil law, and expounds to the Turks all that must be believed and obeyed" (Mikes, 2000: 232). According to Kant's definition, as mankind awakes from immaturity during enlightenment, it means the completion of mankind's maturity with rational thought and experimentation as its biggest instruments in a sense. However, in this quotation that reveals his opinion of "Alkoran" full of futility and childishness it is evident that Mikes refers to the "other" religious book with a derogatory language, which distracts his mind from maturity and enlightenment values. His perception of enlightenment ideologies and his standing in the face of another religion is controversial and contradictory because of his degrading perspective and demeanor. In his book entitled Enlightenment Orientalism: Resisting the Rise of the Novel, Sirinivas Aravamudan presents two different perspectives of orientalism by Kant and Said comparatively: "enlightenment is thought of in monist and meditative terms, as a form of individualizing self-improvement by Kant, 
whereas Said's Orientalism is caught in a dualistic logic of self and other, whereby the Occident's domination of the Orient launches into maniacal hyperproductivity" (Aravamudan 2012: 2). Writing these letters enabled Mikes to perform his intellectual capacity, and as part of leisure activity, he proactively made a self-evaluation while observing and analysing his exterior environment, which has a parallelism with Kant's description of self-improvement and the ideals of enlightenment in his intellectual pursuits.

\section{Conclusion}

A privileged and distinguished woman traveller in her time, Lady Mary Wortley Montagu dealt with female emancipation and how it is represented in different cultures through her vivid orientalist descriptions in Letters. She was a priviliged travel writer because of her direct access to baths, harem (seraglio) and the Sultana's chambers within the Ottoman Empire. These advantages enabled her to contextualize her observations and provide us with a more elaborate perception of life in the 'Orient', which represents a world of mystery, romance, and intrigue for the Occident. The experience of observing and analyzing "the other" culture in accordance with its own value judgments and seeing herself from the eyes of others gave Lady Mary Montagu a great chance to stand out as one of the most influential and distinguished travel writers. Offering a secular perspective on the Muslim Orient by an elite, aristocratic woman, Letters defies the restrictive social attitudes towards women that hindered their intellectual and social growth. Lady Montagu is distinguished from other Oriental writers because of her authentic description of women, including real women she encountered personally and interacted with in real life. She mostly expressed both her amazement and admiration for the Ottoman culture, law, domestic life and moral values instead of talking about the 'other' culture in derogatory way. Her access to harems while living in Constantinople enabled her to compare Turkish women's living conditions with her life in England. She observed that Turkish women had more freedom than they had in England. Her Embassy letters reflect Lady Mary Montagu's life experiences and enlightens the wrong ideas about the Orient with an unbiased lens through the Ottoman lifestyle during the imperial period. She subverted the common assumptions about the oppression of Muslim women in her embassy letters. She employed her travel experiences within the Ottoman empire as a way of defining her own identity and her home country. Said's argument is supported by Montagu's oriental perspective because she had the opinion that European culture and society were superior to Ottoman society although Montagu had a benevolent manner towards the Ottomans and approved them in many examples in her letters. Furtehrmore, Lisa Lowe observes: "Montagu relies on and reiterates an established cultural attitude that differentiates Orient and Occident, that constitutes them as opposites." (Lowe 1991: 32)

On the other side, Letters from Turkey which was written in an epistolary form is centered upon Mikes's life between the years 1717 and 1758. This epistolary narrative form that was very popular in Mikes's time helped Mikes to depict his perspective, feelings and perception of the "other" culture (Turkish culture) as well as Greek and Hungarian cultures to some extent. Contextually these letters refer to the cultural and political events that took place in the succession of Sultans and Vezirs during his exile in the Ottoman Empire besides agricultural practices and natural events in the daily life of Turkish people. In this epistolary form Mikes combines his personal thoughts and feelings with an informative tone in the role of a conveyer of cultural elements about Rodosto ruled by Ottomans in the $18^{\text {th }}$ century. As part of the case of otherization, he exalts Hungarian nationalistic values while he labels other European societies or the Ottoman Empire in a derogatory way in his letters. In his letters, we can feel his strong sense of Hungarian identity and his steadiness in maintaining his cultural and religious customs and values in his elaboration of his own and the "other" culture, while his praising the benign and merciful ruling style of Sultans offers a different view of orientalism in favour of the "other" culture (Ottoman Empire). As a result of enlightenment orientalism regarding the effort of the western world for self-identification can be associated with Mikes's social comments on Persian, Greek, Ottoman and Turkish culture and religion, as well as his tendency to compare and contrast his own culture and religion in a diminishing tone at times. The common prejudice that Islam religion, or the Turkish religion cursing and disrespecting Jesus Christ is rejected by Mikes in parallel with enlightenment orientalism. Mikes disproves this wrong belief through his own experiences in the light of the developments of 18th century enlightenment.

The Ottoman Empire (the East) and Europe (the West) have always regarded each other as "the other" throughout their histories and this attitude of alienation has led to the creation of stereotypical racist images and the depictions of other cultures and societies through binary oppositions and specific oriental terms. In Letters from Turkey Kelemen Mikes presents his ideas and observations of other people. What is striking is, on the contrary to the general attitude, that both Kelemen Mikes and Lady Montagu's letters are the first-hand reflections including their personal and moral 
views as well as their impressions on the "Other", as self-fashioning is "conditioned by the expectations of their class, gender, religion, race, and national identity" (Greenblatt, 1990: 15). While these narratives display how their writers complete their self-fashioning, and how they modify and reframe their oriental perspectives in the light of their traveling experiences and cultural observations, they also contribute to historiography, and literature within interdisciplinary cultural studies as well as comparative studies. This study tried to examine Lady Mary Wortley Montagu and Kelemen Mikes's letters from their political, religious and ethnical perspectives and trace several relationships that have allusive discussion relativity in the discourse of Saidian and Aravamudan's Orientalism. Said quotes Karl Marx in the epigraph of Orientalism: "they cannot represent themselves; they must be represented". As a consequence of this orientalist discourse, stereotypical representations of the Occident is created as "essentially rational, developed, humane, superior, authentic, active, creative, and masculine" while the Orient is represented as "irrational, aberrant, backward, crude, despotic, inferior, inauthentic, passive, feminine and sexually corrupt" (Macfie, 2002: 8). Said depicted the world with the hegemony of the superior Occident over the inferior Orient and he claimed that the Orient exists as a foil, something to "help define Europe as its contrasting image" (Said 1979: 1-2). While the creation of these two unequal halves is European based according to Said, the perception of the Orient as a binary demonstrates that European power is prevalent throughout Montagu's letters. Hence, the representation of the Turks in Turkish Embassy Letters by Lady Mary Wortley Montagu and Letters from Turkey by Kelemen Mikes unquestionably contributes to Orientalist imagery and ideals, and reflects the perspective of English self-fashioning.

\section{References}

Aravamudan, S. (2012). Enlightenment Orientalism: Resisting the Rise of the Novel. Chicago: The University of Chicago Press.

Aydın, Y. (2015). Bir Yabancı Gozüyle Tekirdağ: Kelemen Mikes'in Türkiye Mektupları.

Desai, A. (1999). 'Introduction', in M. W. Montagu, Turkish Embassy Letters. Athens, University of Georgia Press, p. xxxii. Montagu, M. W. Letters. Knopf. 1992.

Gingrich, A. (1996). Frontier Myths of Orientalism: The Muslim World in Public and Popular Cultures of Central Europe. Mediterranean Ethnological Summer School, II.

Gömörl, G. (1976). Tradition and Innovation in the Literature of the Hungarian Diaspora. Books Abroad, 50(2), 303-307. https://doi.org/10.2307/40130431

Greenblatt, S. (1990). Resonance and Wonder. Bulletin of the American Academy of Arts and Sciences, 43(4), 11-34. https://doi.org/10.2307/3824277

Greenblatt, S. (2012). Renaissance Self-Fashioning from More to Shakespeare. The University of Chicago Press.

Heffernan, T. (2000). Feminism Against the East/West Divide: Lady Mary's "Turkish Embassy Letters". Eighteenth-Century Studies, 33(2), 201-215. https://doi.org/10.1353/ecs.2000.0009

Jensen, L. (2016). The Roots of Nationalism: National Identity Formation in Early Modern Europe, 1600-1815. Amsterdam: Amsterdam University Press. https://doi.org/10.5117/9789462981072

Kelemen, M. (2000). Letters from Turkey. London: Kegan Paul International.

Lewis, B. (1968). Some English Travelers in the East. Middle Eastern Studies, 4(3), 296-315. https://doi.org/10.1080/00263206808700105

Lowe, L. (1991). Critical Terrains: French and British Orientalisms. Ithaca: Cornell Univ. Press.

Macfie, A. L. (2002). Orientalism. Longman, London.

Montagu, M. W. (1992). Letters. New York: Everyman's Library.

Said, E. W. (1979). Orientalism. New York: Random House.

Said, E. W. (2003). Orientalism: Western conceptions of the Orient. Penguin Books Limited.

Secor, A. (1999). Orientalism, Gender and Class in Lady Mary Wortley Montagu's 'Turkish Embassy Letters: to Persons of Distinction. Men of Letters \& c. Ecumene, 6(4), 375-398. https://doi.org/10.1177/096746089900600401

Yegenoğlu, M. (1992). Supplementing the Orientalist Lack: European Ladies in the Harem. Return to Inscriptions, 6, 
45-80.

\section{Copyrights}

Copyright for this article is retained by the author(s), with first publication rights granted to the journal.

This is an open-access article distributed under the terms and conditions of the Creative Commons Attribution license (http://creativecommons.org/licenses/by/4.0/). 